Documentation et bibliothèques

DOCUMENTATION BIBLIOTHEQUES

\title{
Information: People still count
}

\section{El individuo todavía tiene sus valores en la información}

\section{Beth Miller}

Volume 32, numéro 1-2, janvier-juin 1986

URI : https://id.erudit.org/iderudit/1052708ar

DOI : https://doi.org/10.7202/1052708ar

Aller au sommaire du numéro

\section{Éditeur(s)}

Association pour l'avancement des sciences et des techniques de la documentation (ASTED)

ISSN

0315-2340 (imprimé)

2291-8949 (numérique)

Découvrir la revue

Citer cet article

Miller, B. (1986). Information: People still count. Documentation et bibliothèques, 32(1-2), 27-28. https://doi.org/10.7202/1052708ar

\section{Résumé de l'article}

En commentant le thème du congrès conjoint ASTED-CLA, la présidente de la Canadian Library Association rappelle le besoin d'humaniser les services à une époque où la technologie et le progrès occupent toute la place. Elle invite de plus les lecteurs à réfléchir sérieusement sur l'avenir des bibliothèques et le rôle futur des spécialistes de la documentation.
Tous droits réservés (C) Association pour l'avancement des sciences et des techniques de la documentation (ASTED), 1986
Ce document est protégé par la loi sur le droit d'auteur. L'utilisation des services d'Érudit (y compris la reproduction) est assujettie à sa politique d'utilisation que vous pouvez consulter en ligne.

https://apropos.erudit.org/fr/usagers/politique-dutilisation/ 


\title{
Information: People still count
}

\author{
Beth Miller \\ President \\ Canadian Library Association
}

En commentant le thème du congrès conjoint ASTED-CLA, la présidente de la Canadian Library Association rappelle le besoin d'humaniser les services à une époque où la technologie et le progrès occupent toute la place. Elle invite de plus les lecteurs à réfléchir sérieusement sur l'avenir des bibliothèques et le rôle futur des spécialistes de la documentation.

\section{Information: People still count}

In discussing the theme of the Joint ASTED-CLA Conference, the President of the Canadian Library Association stresses the need for personalised services in an era when technology and progress occupy a large place. She invites the readers to think seriously about the future of libraries and the future of information professionals.

\section{El individuo todavia tiene sus valores en la información}

Al comentar el tema del congreso organizado conjuntamente por la ASTED y la CLA, la presidenta de la Canadian Library Association menciona la necesidad de humanizar los servicios en una época en que la tecnologia y el progreso tienen mucha importancia. Asimismo, sugiere a los lectores que reflejen seriamente sobre el porvenir de las bibliotecas asi como sobre el papel futuro de los especialistas de la documentation.
In Arthur Kroker's thought provoking work Technology and the Canadian Mind, he notes that the modern century is fully ambiguous charged with opposing tendencies towards domination and freedom, radical pessimism and wild optimism. We live now with the great secret and equally great anxiety that the technological experience is both orwellian and hopelessly utopian. Indeed, central to the human situation in the twentiethcentury is the profound paradox of modern technology as simultaneously a prison-house and a pleasure palace.

Yet, for some, the predicament of human destiny in the age of technology can be more accurately expressed in the words of Lewis Carroll:

\footnotetext{
"He thought he saw a banker's clerck

Descending from a bus.

He looked again, and saw it was

A hippopotamus.

"If this should stay to dine," he said

"There won't be much for us".
}

These interpretations assume there is a hostile, antagonistic confrontation between the possibilities of electronic innovations on the one hand, and the sluggish resistance of conservative libraries on the other. A second stems from assumptions about prophecy: one element of these is prehistoric and reflects the forgivable human wish to foresee the future whether by reading sings or consulting oraclers. The second assumes that if something can be imagined as possible, it will, necessarily become actual, sooner or later.

We see libraries facing increasing demands from their users for a wider range of services, many of which involve the use of technological development. At the same time, there continues to be a majority of users who will continue to rely on material immediately available at their local branch library of service point. And it is self-evident to point out that the bulk of information will continue to be stored and transmitted in printed form for many years to come. What is required is an approach which brings together information, however it is stored, which concentrates on the value of the information to the user, and which presents this in the most appropriate medium. Such information should remain available in printed form both to facilitate retrospective analysis, and to make it available to users who do not have access to electronic systems.

For while the changes taking place in library technology promise many exciting new possibilities for patrons and administrators alike, they bring with them a common challenge: to provide a wider range of user service. 
Yet economic constraints will continue to press libraries to economize, standardize procedures, reduce staffing and make more efficient use of existing facilities, monies and personnel. In addition, there is always the concern that shrinking budgets and fees for service can have the same result as censorship in limiting public access to ideas. As a result, another overriding concern emerges: for while the developments in library technology will enable libraries to provide researchers with more information than ever before, they will pose complex management problems.

Therefore, as we continue to seek out imaginative strategies for utilizing technology, we must continue to pursue goals that converge in the mutual task of gaining access to information as a means of enrichment for the individual and of development for society.

But we must remember that for library staff and library patrons, changing times and new environments can create a new set of pressures that need new insights, new skills, new orientations, and new roles.

The threat of change arouses anxiety when it is still just a threat and not an actuality, while too many possibilities are still open, and before people can experience themselves in the new state.

But not all change is negative, even though it may create uncertainty. Change can be exhilarating, refreshing - a change to meet challenges. Change brings opportunities when people have been planning for it, are ready for it, but staying ahead of change means anticipating the new actions that external events will eventually require and taking them early, before others, before being forced, while there is still time to exercise choice about how and when and what - and time to influence, shape of redirect the external events themselves.

Thus, the problem before us is not to invent more tools, but to use the ones we have. Living with change need not imply insecurity, but, rather, developing new forms of security. It will be necessary to establish a climate which will encourage new ideas, constructive internal competition, one which supports the dignity of the individual, the developing in staff a sense of fulfillment and enthusiasm for the job. Personal contribution must be recognized and challenged through tasks that carry with them variety and opportunity, and which engender a strong sense of personal responsibility.

The dignity of any occupation is that it creates a fellowship, that it binds people together in a common purpose with a common language. In an innovating organization, security will come from flexibility, from quick reaction time, to get the best combinations of people for the job. For security will come from identification with the whole institution, with its unity of effort. The new security will be based on pride in individuals and their talents reawakening or reinforcing the spirit of enterprise in all employees at all organizational levels.

The institutions that will succeed and flourish in the times ahead will be those that have mastered the art of change: creating a climate encouraging the introduction of new procedures and new possibilities, encouraging anticipation of and response to external pressures, encouraging and listening to new ideas from inside the organization.

The individuals who will succeed and flourish will also be masters of change: adept at reorienting their own and others' activities in untried directions to bring about higher levels of achievement. They will be able to acquire and use power to produce innovation.

Thus, in this historic and unique ASTED/CLA Joint Conference members of the library community from all across this vast and marvellous country, Canada will come together to examine ways to ensure the importance of the individual's needs, concerns, talents, hopes in the rapidly growing world of technology. 